LinguistikTerapan14(3) (2017): 213-222

Jurnal Linguistik Terapan Pascasarjana

Available online http://jurnal.unimed.ac.id/2017/index.php/JLT-

Unimed

\title{
LINGUISTIC CHARACTERISTICS OF MALE \\ AND FEMALE STUDENTS WITH DIFFERENT CULTURES IN USING LANGUAGE IN BOARDING HOUSE
}

\author{
Herois Theresyah Simaremare \\ Sri Minda Murni \\ Amrin Saragih
}

Diterima September 2017; Disetujui Oktober 2017; Dipublikasikan Desember 2017

\begin{abstract}
This article aims to investigate the linguistics characteristics of male and female students with different cultures in using language in boarding house. The method of the study is descriptive qualitative research. Qualitative research focuses on understanding social phenomena and providing rich verbal descriptions of setting, situations, and participants. It means the data are in the form of words and sentences. The data is taken from 4 males and 4 females students who live in boarding house. The sample of this research will be taken through random sampling technique. This research has indeed revealed a unique gender differences between Bataknese and Karonese students. The results of this study find out that there are no consistent characteristics of male and female students with different cultures in using the language in boarding house. Male use the female's linguistic characteristics, such as: declaration with interrogative intonation, tag question, emotional reference and high of politeness, vice versa, female uses the male's linguistic characteristics, such as: direct, judgement adjectives, less of politeness and brief sentences. Indeed, this study find out that Bataknese female students are more dominant use male's linguistic characteristics.
\end{abstract}

Keywords:gender, linguistic characteristics, language use, culture, utterances

How to Cite: Herois (2017).Linguistic Characteristics of Male And Female Students With Different Cultures In Using Language In Boarding House.Jurnal Linguistik Terapan Pascasarjana Unimed, 14(3): 213-222

ISSN 2407-7410

\section{INTRODUCTION}

Language exists as a system of symbol, in terms of abstract thinking and senses; it reveals a method and pattern to describe the objective world (Dong, 2014). Human beings not only created language, but also become the users; therefore, the study on linguistics should not only be made from 
the perspective of symbol, but more should be people-oriented. But the most significant difference between human beings is the gender difference, so people of different genders from either physiology or psychology in the use of language will have their own gender characteristics, which leads to the gender differences in language. Gender differences in language are not only regarded as a linguistic phenomenon but also as a social phenomenon.

Gender differences are the fundamental facts of social life and human differences. It reflects that there is a long historical origin in language difference phenomena. Men and women have different status and play different roles, thus they have different duties and different rights. In social interaction, men and women have different interests in choosing their conversation topics. When men are talking, they are more likely to choose the topics of politics, economy, stocks, sports, current news. While women have more interest in talking family affairs, such as the education of children, clothes, cooking, fashion, etc. Women's talk is associated with the home and domestic activities, while men's talk is associated with the outside world and economic activities.

The gender differences in language are not invariable (Dong, 2014). The gender difference phenomenon in language is reflected by the age, status, social environment, culture background and experience. Based on that phenomena, it is believed that male and female have the differentiation in using the language based on some factors. Therefore, this study seeks to answer the following research question:"What are the linguistic characteristics of male and female students with different cultures in using the language in boarding house?"

\section{LITERATURE REVIEW}

Gender is not a noun a "being" but a "doing". Gender is created and reinforced discursively, through talk and behavior, where individuals claim a gender identity and reveal it to others (West\&Zimmerman, 1987). Uchida (1992:61) stated that men and women even those within the same group, live in different or separate cultural worlds, they promote different ways of speaking. In simple terms, although men and women live in the same environment, they establish different relation with society as if each belonged to a different environment and culture, the result of which is consequently reflected in the language of both gender as in other aspects of their lives. Male and female also have their own characteristics which are shown by gendered characteristics when they communicate with others.

In male and females' spoken language, some linguists have observed that there are some characteristics which exists and showed gendered characteristics of men and women when they are talking and interacting with others. Crawford (1997) pointed out the men's language characteristics in communication can be identified in the terms of direct, judgement activities, brief sentences, selfreferences, slang or swear words and politeness. Lakoff in Holmes (2013) pointed out the women's language characteristic can be identified in the terms of lexical hedge or fillers, rising intonation on 
declaratives, tag questions, "empty adjectives", precise color terms, intensifier, hypercorrect grammar, superpolite forms, avoidance of strong swear words, emphatic stress.

\section{METHODOLOGY}

This research is conducted systematically by following the technique of data collecting and data analysis. The data in this study was taken from the utterances gathered from the conversation between males and females students. The source of data was four males and four female students with different cultures in boarding house. The participants for this case study are selected randomly. There are four males and four females students selected to be participant and they are made up of different culture. Two of the male participants are Bataknese and two of male participants are Karonese. Vice versa, two of female participants are Bataknese and two of female participants are Karonese. They all have known each other because they have lived in that boarding house for almost two years. Permission was also obtained from them to participate in this research and informed that their identities would be kept confidential and the purpose of this research was also explained to them.

The technique of data collection will be used documentary technique. The data will be collected through 3 steps, they are observing, recording and transcribing. The observation will be used firstly. The researcher will be applied the direct observation when participant are engaged in conversation. As Bogdan and Biklen (1982) say that observation is one of the common ways in qualitative research since qualitative research is naturalistic. In this study, observation will be done during the participants are engaged in conversation. Then, the utterances produced by male and females students will be recorded during they are engaged in conversation. The main purpose of recording is to be able to get the natural data. Then, the utterances will be transcribed in order to organize the data.

\section{RESULT AND DISCUSSION}

After analyzing the transcripts of conversations of both genders and the data analysis based on themes or categories, each of the use of the linguistics characteristics of men and women are described as follows.

\section{The male students use both "direct" and "declaration with interrogative intonation"}

The direct sentence is the using of imperatives as the realization of their status and power in interaction. An imperative can direckly control different aspects of another person's thinking or behaviour. This is commonly used by man to show their power and status (Crawford, 1997). By using the concept as the category of data analysis show that man perform the direct sentences as follows:

M1 :Kuncikan pintu itu,cepat. (Lock the door, hurry up)

M3 :Suka kali kalen nonton sinetron, ganti siarannya.

(You like watching the drama very much, change the channel!)

(Conversation 1) 
M4 :Kupake dulu uangmu (Give me your money!)

M1 :Susah kali kau buat, ini dia.(You make it difficult, here you are)

(Conversation 3)

In these two conversations, we can see that males utterances, "Lock the door, hurry up!; Give me your money!" are formed in the imperative form and function as the direct command. The use of direct command is considered as the realization of his status as a man who is more powerful than woman. This is in line with what Crawford (1997) said that man's utterances are mostly imperative intended to be the realization of his powerful position as a man.

However, man does not perform such linguistic characteristics behaviour consistently in every situation. Some men perform linguistic characteristics of women, such as declaration with interrogative intonation, as seen in the conversation below:

M2 :Bisa tutupkan pintu itu dek, tolong?

(Would you mind to close the door, sister?)

(Conversation 3)

This utterances do not reflect the man linguistic characteristic, this utterance is formed in interogative intonation and in polite way. The power that the man has is not realized in his utterance. He choose to realize the less powerful position that usually held by woman instead by realizing the more powerful position as a woman usually does. As a man, he should be said, "Close the door?"

\section{The male students use both "judgement adjectives" and "tag question"}

The judgement adjective is the way of expressing one's thinking, evaluating, or judging an object such as being good or bad. That is commonly conducted by the use of adjective. This is commonly performed by a man to show the power (Crawford, 1997). By using the concepts as the category of data analysis show that man perform this adjectives, as seen in conversation below.

M3 :Apanya kau bilangi? Selalu bahasa planet?(What are you talking about? You usually use the strange words)

F3 : Makanya blajar bahasa planet bang..

(Learn the strange words, brother)

(Conversation 4)

In conversation 4, we can see the utterance, " (What are you talking about? You usually use thestrange words)" is formed in the judgement adjectives to tell his opinion. He stated that thefemale is proud of herself by using the uncommon words (in this sense, she used vernacular language). This is line with what Crawford (1997) said that man's utterances are mostly judges something by using adjectives to show their power in their interaction.

However, male students does not perform such linguistic characteristics consistently in every situation. They also perform linguistic characteristics of woman, such as tag question, as seen in conversation below:

M2 : Iala, kamu, Siapalagikalobukankamu, iakan?(Of course you are, aren't you? 
F1 : Malas. Seru kali film ini.Jangan ganggu dulu.(I'm lazy. This film is so interesting. Do not disturb me)

(Conversation 1)

In this conversation, the male's utterance is formed in tag question to make sure that he asked the girl to lock the key. The male doesn't show his powerness to facilitate the conversation. As a man, he should be said, "I ask you, to lock the door".

\section{The male students use "self references" and "emotional references"}

Self reference is when the idea or formula refers to its self. It refers to the ability of a subject to himself/herself to have the kind of thought exrepressed by the first person nominative singular pronoun. (Crawford, 1997). This is commonly use by male to show his power. It can be seen in the conversation below:

M3 : Lebih banyaknya aku tau dari dirimu. Namanya udah berpengalaman.(I know more than you. I had had so many experiences)

F2 : Yakin?(Are you sure?)(Conversation 4)

The male utterance, "I know more than you. I had had so many experiences" is formed in the form of self references. It is reflected from the word " $I$ " that used by male. The function of the word is to emphasize that the male is more powerful. It is line with Crawford theory (1997), the man's utterances are mostly used the self references intended to be the realization of his powerful position in society.

However, man does not perform the linguistic characteristic of woman, such as emotional references, as seen in data below:

M3 : ya ampun. Baiknya anak yang satu ini. Terlambat menyadarinya.(Oh my God, you are so good, It's too late too aware this)

F1 : mmmmm, Leseng naipoang.(He mocks me)

(Conversation 3)

In this data, the male utterance, "(Oh my God, you are so good, It's too late too aware this) do not reflect the man's linguistic characteristics. The utterance is formed in the form emotional references and in polite way to state his feeling. The power of man is not realized in his utterance. 4. The male students use both "less of politeness' and "high of politeness".

Less of politeness make the speaker in the superior position in their interaction. They use the language direckly and seldom to keep interlocutor's feeling when talking with them. (Crawford,1997). This is commonly use by man to show their power as a man, as seen in the data below:

M1 : Kuncikan pintu itucepat!(Lock the door, hurry up!)

F1 : Akunya bang?(Me, brother?)

(Conversation 1)

M3 : Yang udah makannya kalian?(Have you already had your dinner?)

F1 : Udah dek.(Yes, I have). 
M3 : Ko ga ngajak-ngajak?(Why don't you invite me?)

(Conversation 4)

The males utterances, "Lock the door, hurry up!; Have you already had your dinner?; Why don't you invite me" are formed in the impolite words, because in this utterances, the male show their powerful position. This is line with Crawford theory (1997) said that man's utterances are mostly less of politeness to show their status and powerful position as a man. They do not want to keep the cooperation in their interaction by keep someone's feeling.

However man does not perform such linguistic characteristics consistently in every situation. Some men also perform linguistic characteristics of woman such as, high of politeness, as seen in data below:

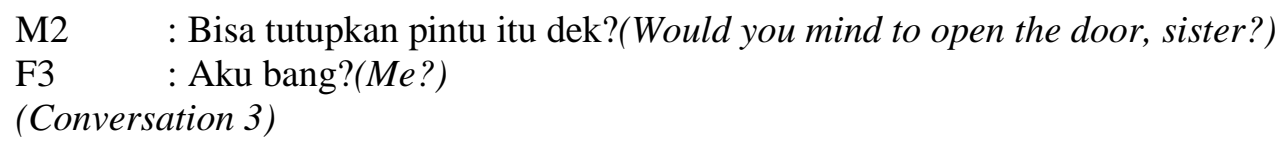

The male utterances, "Would you mind to open the door, sister?; is formed in polite way to keep someone's feeling. He used the word, "would you" to show his lower position when asking someone's helping. He does not use his language characteristics to show his power as a man.

The data analysis show that woman does not use the women's linguistics characteristic consistently, she may also use the men's linguistic characteristics, each of the use of the linguistic characteristics of females students:

1. The female students use both "declaration with interrogative intonation" and "direct"

Declaration with interrogative intonation is making the statement into question by raising the pitch of the voice at the end of the statement to show the uncertainty. This is commonly performed by woman to show their powerless (Lakoff, 1975). By using the concept as the category of data analysis, show that woman perform the declaration with interrogative intonation, as seen in the data below:

F3 : Siapalagi kalo bukan cewek-cewek cantik di kos ini, bukan?(Who is anything else? Of course, we are. Aren't we?)

M2 : Puji diri terus.(Praise your own self)

F2 : Memang cantik-cantiknya kami khan?(We are beautiful, aren't we?) (Conversation 2)

F1 : Cewek kan unik bang. Ciptaan Tuhan yang paling sempurna. Ia khan? (Girls areunique. They are the perfect creation of God, aren't they?)

M1 : Apa?(What)

In this data, these utterances are formed with indirect sentences, woman make statement into questions, the interrogative intonation has function to express her uncertainty about something and asking for someone's confirmation. It can be seen in the utterance "We are beautiful, aren't we?; Girls are unique. They are the perfect creation of God, aren't they?" This is line with Lakoff (1975) said that woman's utterances are mostly indirect and formed in the interrogative sentences to express their powerless position. 
However, women does not perform such linguistic characteristics consistently in every situation, some women also perform linguistic characteristic of man, such as direct sentences, as seen in the data below:

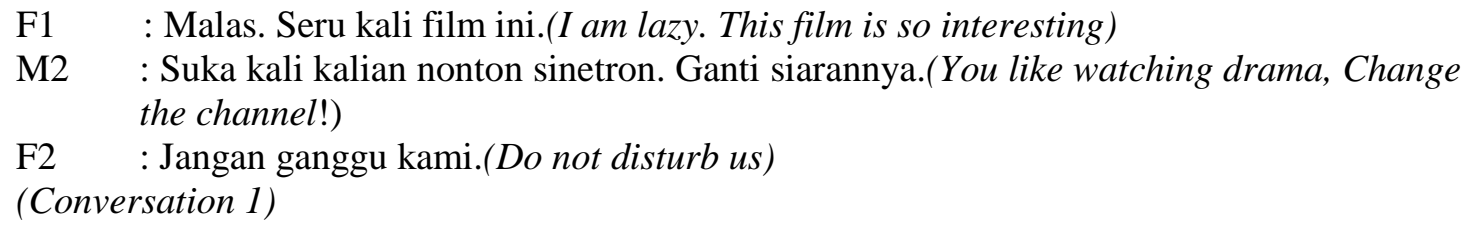

In this data, the female utterances do not reflect the woman's language characteristics. The uterance, "Do not disturb us" is formed in direct sentences. It is used to forbid someone. She uses the direct language to show her power as a woman. As a woman, she should be said, "Please, do not disturb us".

\section{The female students use both "tag question" and "judgement adjectives"}

Tag question is stating the claim but has less confidence to state it to the interlocutor. And tag question used to show the insecurityof something. This is commonly performed by woman to show her powerless (Lakoff, 1975). By using the concept as the category of data analysis show that woman use tag question as seen in the data below:

F3 : Siapalagi kalo bukan cewek-cewek cantik di kos ini, bukan? (Who is anything else? Of course, we are. Aren't we?)

M2 : Puji diri terus.(Praise your own self)

F2 : Memang cantik-cantiknya kami khan?(We are beautiful, aren't we?)

In this data, there utterance, "Who is anything else? Of course, we are. Aren't we?; We are beautiful, aren't we?) are formed in tag question to show the insecurity of something. The use of tag question is considered as the realization of her powerless. It is line with Lakoff (1975) said that woman's utterances are mostly indirect to realized their powerless position in the family.

However, woman does not perform such linguistic characteristics consistently in every situation.Some women also perform the linguistics characteristics of man, such as judgement adjectives.

F4 : Ooooo. Yang banyakan tugas ini. Mini research, critical book review, critical journal review, project entah apalagi. Ga tau ngerjain apa duluan.(There are so many assignment. Mini research, critical book review, critical journal review, project and many others. I'm confuse, where do I start?)

F3 : Iakan? Ga ada perasaan dosen ini.Uda mau UAS, tugas lagi, tugas lagi.(That's right? They are callous. We will get final term next two weeks, but we are busy with assignments. How can we focus to our final term?

F4 : Coba mereka yang jadi mahasiswa. Pasti ga sanggup, Omong kosong (If they are students, of course, they will not do it, bullshit)

The utterance, "If they are students, of course, they will not do it, bullshit" do not reflect the woman's language characteristics. The utterances are formed in the judgement adjective and impolite way. The 
powerless that the woman has is not realized in her utterances. She judges their lecturers direckly because of they have so many assignment in the end of semester.

3. The female students use both "high of politeness" and "less of politeness'

High of politeness is the way of talking when speaker really keep the interlocutor's feeling and make them into superior position, it can be seen from the politeness markers such as, "Please, Thank You" (Lakoff, 1975). This is commonly performed by woman to show her powerless position. By using the concept as the category of the data analysis, show that woman perform the high of politeness as seen in the data below:

M2 : Bisa tutup kan pintu itu dek?(Would you mind to open the door, sister?)

F3 : Aku bang?(Me, brother?)

F1 : Akulah yang nutup bang?(Can I close the door for you, brother?)

M3 : Ya ampun. Baiknya anak yang satu ini. Terlambat menyadarinya.(Oh my God, you are so good, It's too late too aware this)

(Conversation 3)

The utterances, "Me, brother?; Can I close the door for you, brother?)are formed in polite markers when asking someone. These utterances are considered as the realization of her powerless as woman, she wants to show her respect to the man as her senior. This is line with what Lakoff (1975) said that woman's utterances are mostly use the high politeness in order to keep someone's feeling and make the speaker in the inferior position.

However, women does not perform such linguistic characteristics consistently in every family, some women also perform the man's language characteristics, such as less of politeness, as seen in data below:

F1 : Siapa, siapa yang menggosip? (with higher intonation)(Who's? Who's the gossiper?)

M1 : Kalian lah.(All of you)

F1 : Sembarangan ngomong.(Bullshit)

(Conversation 2)

The utterances, "Who's? Who's the gossiper?; Bullshit" do not reflect the women's language characteristics. The utterances are formed in impolite way. She said the words to blame her friends and to state that her interlocutor is wrong. She use the impolite words as the realization of her power position.

4. The female students use both "hedging" and "brief sentences"

Hedging is the way to show the disagreement but stated in the non-absolute language, such as "I think, I guess" to show the uncertainty about something (Lakoff, 1975). This is commonly performed by women to show their powerless position in society. By using the concept as the category of the data analysis, show the woman perform the hedging.

F3 : Emang ia bang. Banyak kali berita criminal akhir-akhirini, bagusan pindah ke planet lain khan?(I guess so. There are so many criminal reports lately. It's better we move to the other planet) 

criminal reports lately)(Conversation 4)

The utterances, "I guess so, I think so" are formed in a hedging sentences. the utterances show the urcentainty of something, by this words woman realized her powerless in community. This is line with what Lakoff (1975) said that woman's utterances are mostly use the uncertainty expression when talking with someone, to show their powerless position in the community.

However, women does not perform such linguistic characteristics consistently in every family, some women also perform the man's language characteristics, such as brief sentence, as seen in the data below:

F2 : Jangan!!! Jangan ganti.(No, Do not change it!)

M3 : Apa gunanya nontonsinetron(Is it important to watching drama?)

F1 : Perlulah.(Yes, of course yes)

The utterances, "No, Do not change it! Yes, of course yes" do not reflect the woman's language characteristics. The utterances are formed with the clear and brief sentences. The powerless of women is not realized in her utterances. She use the short and clear sentences to make the point briefly to the interlocutor. She use the word to realize her power position that usually held by man instead of realizing the more powerless position as a women usually does.

\section{CONCLUSION}

Based on the data analysis, it can be concluded that there are no consistent characteristics of male and female students in using the language in their interaction in boarding house. Men use the man language characteristics and also use the women language characteristics to show their powerfulness and cooperation in interaction. Vice versa, women use the woman language characteristics and also use the men language characteristics to show their powerlesness and cooperation in interaction. On the other hand, it is found that female speech is very much influenced by their choice of linguistic forms. They prefer to use a lot of questions to enquire about information which indirectly helps to develop quite a fair participation especially in terms of turn taking by all the interlocutors. Thus, women often use the brief sentences to switch from one topic to another topic in a shorter time.

Despite some of these distinctive features in men's and women's speech, it is also discovered that men and women share the same features in their speech in terms of directness and indirectness in speech. Both genders are direct although there are some instances whereby they are indirect in their speech. This is clearly demonstrated as there are no terms in the ethnic groups which can be used in place of "please, may, could etc". Hence, their speech may sound direct and rude to other interlocutors. Notably, men used slightly more of fillers, hedges and affirmatives than women. This finding is in contrast with findings by Lakoff (1975) who found that women used more fillers, hedges 
and affirmative words than men. Both genders use very little of these linguistic features probably because they are communicating using their ethnic or first language which they are fluent and competent in. Furthermore, the topics of their conversation do not require them to give factual information. They are just talking about petty issues relating to their daily lives, hence, they do need to think hard about what to say.

Indeed, this study find out that Bataknese female students are more dominant in using the male's linguistic characteristics. Thus, for further research, it is suggested to find out the reason, why does the Bataknese female are more dominant in using the male's linguistic characteristics. Since the subjects of the study are limited to the students who live in boarding house, it is suggested for further research to find out the linguistic characteristics used by students in different context, such as campus, classroom, canteen or public context.

\section{REFERENCES}

Bogdan, R., \&Biklen, S. (1992). Qualitative Research for Education. Boston: Allyin and Bacon.

Crawford, M. (2003).Talking Difference on Gender and Language. Thousand Oaks, CA: Sage.

Eckert, P., \&Ginet, S, M. (2003).Language and Gender. Cambridge: Cambridge University Pres.

Lakoff, R. (1975). Language and Woman's Place. New York: Harpet and Row.

Meyerhoff, M. (2006).Introducing Sociolinguistics. New York: RoutledgeTylor and Francis Group.

Nemati, A., \& Bayer, J. M. (2007) Gender Differences in the Use of Linguistic Forms in theSpeech of Men and Women: A Comparative Study Of Persian And English.Retrieved.April 16, 2010 ,http://salr.net/

Tannen, D. (1990). You Just Don't Understand. United States: Ballantine Books.

West, C., \& Zimmerman, D. (1987).Doing Gender: Gender and Society in Eckert, P. \&Ginet, S, M. 1990. Language and Gender. Cambridge: Cambridge University Press. 